\title{
USING KAHOOT TO IMPROVE STUDENTS' ACHIEVEMENT AND CRITICAL THINKING IN UNDERGRADUATE OF PSYCHOLOGY STUDENTS
}

\author{
Jaka Warsihna ${ }^{1}$, Zulmi Ramdani ${ }^{2}$ and Bagus Hary Prakoso ${ }^{3}$ \\ ${ }^{1}$ Institute of Research and Community Service (LPPM), Indonesia Open University, Indonesia \\ ${ }^{2}$ Faculty of Psychology, UIN Sunan Gunung Djati Bandung, Indonesia \\ ${ }^{3}$ Centre for Educational Assessment, Ministry of Education and Culture, Indonesia
}

\begin{abstract}
Kahoot is one of the most popular evaluation methods used as an effective instrument in the learning process. As a platform of digital-based media, there are many advantages that can be gotten by using it, such as making easier and faster for teacher and lecturer in getting assessment results, reducing of the cost in making and duplicating a couple of questions, and psychologically improving students' attention in understanding material actively and openly. This is a preliminary study which is conducted using experimental design toward 60 of psychology students who attended the research methodology and psychometric courses. The purposes of this study are to explore the psychological factors that might happen during learning Kahoot media and to identify the effect of Kahoot learning in improving student achievement and creating a critical thinking character. The results of this study show that there is a significant difference between pretest and posttest score during the experimental period. Therefore, this preliminary study gives important information about the effectiveness of using Kahoot in the learning process.
\end{abstract}

\section{KEYWORDS}

Critical Thinking, Digital Platform, Kahoot, Psychology Students, Students' Achievement

\section{INTRODUCTION}

Globalization era and the growth of technology has been brought everyone to a deep attachment in all of human life and contexts. That situation also makes a change toward using of learning media and instrument which is more adaptive, especially in giving the accessibility of the information that was gotten (Esteves, Pereira, Veiga, \& Vasco, 2018). The use of technology-based learning media in this digital era allows everyone to get optimal results by simply issuing simple efforts such as online-based media in evaluating student academic performance in the classroom (Boticki, Baksa, Seow, \& Looi, 2015; West, 2013). The use of online learning media will further facilitate and accelerate the implementation of various activities or evaluations in learning.

Much of the research has been done shows the same information, where the use of online-based media in an innovative and certainly efficient media in organizing the educational process (Gómez-Peña, Sifuentes, \& Finch, 2015). One of the platforms that are widely used today is Kahoot's media as an instrument in assessing learning outcomes. With various conveniences and benefits obtained by using this media, it allows each teacher to use it whenever and wherever as long as various facilities and situations around it support the existence of the use of Kahoot (Dellos, 2015; Lin, Ganapathy, \& Kaur, 2018). On the other hand, the use of online-based media such as Kahoot is an alternative media that can be used to foster curiosity and the psychological state of students to be better (Plump \& LaRosa, 2017). Among them are being able to increase psychological factors such as school engagement, intrinsic motivation, student achievement, and other related personal factors (Dellos, 2015).

The results obtained from Kahoot are not much different in terms of accuracy with the classical-based method the paper test (Ramdani, Widyastuti, \& Ferdian, 2018). So that the media can be used directly to get teaching with more interesting methods and the results obtained are probably not much different. There has been a lot of previous research focusing on the use of Kahoot and its effect on student achievement in the 
classroom or in order to improve their various positive personal attributes in school (Dellos, 2015; Ismail \& Mohammad, 2017; Lin et al., 2018; Yapıcı \& Karakoyun, 2017). The use of Kahoot allows students to get more interesting learning method so that they not only increase their awareness of the importance of the material but also increase their efforts to actively learn and enjoy each learning activity. However, not many studies have tried to explore the use of Kahoot's media toward students' critical thinking attributes in schools, even though these psychological attributes are very important as part of higher-order thinking students and also how they continue their plans and lives in society (Amrullah, Tae, Ramdani, Irawan, \& Prakoso, 2018).

Critical thinking is one of the important abilities that students must have in their learning process (Facione et al., 1995). One of these critical thinking skills can be developed using technology-based media such as Kahoot. The existing scheme in using Kahoot allows each student to prepare themselves as well as possible to determine the most appropriate choice they will face in the matter (Lin, Ganapathy, \& Kaur, 2018). As a media with accessibility that is easily accessible to everyone, Kahoot can be one of the online media which then requires its users to think carefully with the answers they will choose because they are faced with limited time and accuracy in choosing answers (Lin et al., 2018). There are not many studies that try to see Kahoot's use of increasing critical thinking, especially in psychology learning. Whereas psychological material has a lot to do with concepts and theories that must be mastered specifically (Ramdani et al., 2018). So the use of online media such as Kahoot can make it easier to memorize and increase students' curiosity about deeper psychological material (Plump \& LaRosa, 2017). This study tries to see the effect of Kahoot's media usage on improving student achievement and their critical thinking processes and how these factors interact in creating a better quality of education.

\section{THEORETICAL FRAMEWORK}

\subsection{Kahoot as Digital Platform}

Kahoot is an online media platform that used to evaluate the results of the learning process. It provides many interesting and useful feature, especially in doing an activity such as quiz, survey, and group discussion about learning (Dellos, 2015). The use of this media is very easy because the teacher practically only moves various questions and related cases that must be completed by students within a certain period of time (Lin et al., 2018). The implementation of activities using Kahoot is certainly very efficient to use in the classroom because the examination can be done together. This platform also provides an attractive display because it contains a collection of visualizations and music that are useful for stimulating not only the student's kinetic body but also to increase their curiosity about the material to be tested (Pede, 2017). One of the challenges that might be faced is related to external factors such as noise and the air temperature around it. In addition, the effectiveness of Kahoot's use can run optimally if it is equipped and supported by adequate of internet facilities.

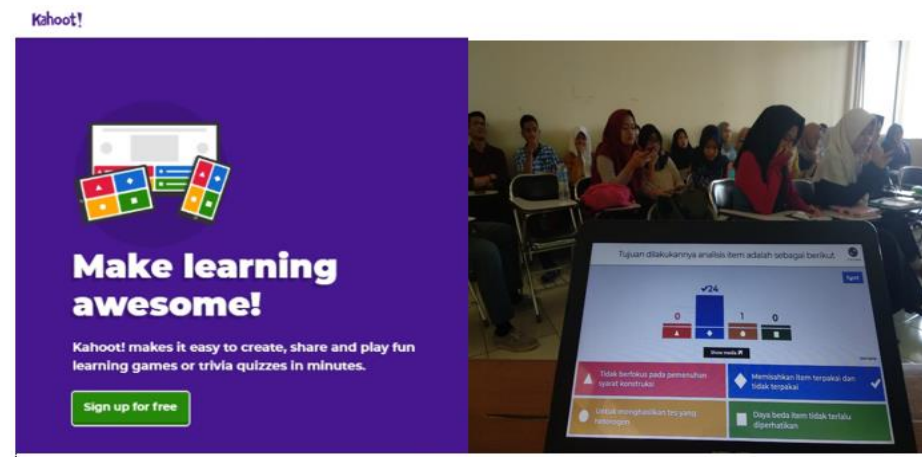

Figure 1. Kahoot platform 


\subsection{Students' Achievement}

Learning achievement is often the main indicator in seeing whether the learning process runs optimally or not. This learning achievement is manifested in various forms and activities all of which stem from the ability of students to understand and learn a material (Dunn \& Kennedy, 2019). As one of the important factors in the learning process, learning achievement is highly related and determined by other factors that only appear personally, but also the influence of other extrinsic factors (An \& Carr, 2017). Learning achievement determines whether can graduate at the next higher stage. The optimal or not a person's learning outcomes depend on how he prepares himself to get the best results. This also determined by the personal students who interact with the environment in which they grow and develop (Liao, Chen, \& Shih, 2019). The use of appropriate media will result in more active and collaborative learning, especially if the learning is designed with technological progress and adapted to the dynamics that occur in the classroom.

\subsection{Critical Thinking}

Critical thinking is an intellectual and structural process which is actively related to the ability in conceptualizing, applying, analyzing, constructing, and evaluating information which is gotten through the process of observation, experience, reflection, reason, and communication (Boa, Wattanatorn, \& Tagong, 2018). According to Sasson, Yehuda and Malkinson (2018), critical thinking is an important part of human life in understanding the complexity of the phenomenon. Critical thinking emphasis the students feel on the problem, having a strong and a clear perspective about the future life, full of consideration in doing tasks, and good at problem-solving and making a decision (Facione, Facione, Sanchez, \& Gainen, 1995). This psychological aspect is closely related to various other aspects of life, such as in filtering information received by individuals, clarifying conflicts that arise, solving a difficult problem, even correcting a decision that might be wrong.

Critical thinking is important to be trained in daily life, especially when individuals get information related to uncertain rumours and issues (Sasson et al., 2018). The theoretical framework of the critical thinking starts from The Delphi Panel (Facione, 1990) by doing identification toward the key elements that might happen in the reasoning process while the critical thinking disposition refers to the human' tendency in dealing with the problem which is based on logical reasoning (Facione et al., 1995). Critical thinking encompasses various aspects that are not only in the form of the critical nature that is created within but also includes a set of abilities that are trained and developed to deal with various difficult and confusing situations. With critical thinking, students are expected to be able to develop themselves better in accordance with the demands of the environment.

\subsection{Kahoot, Students' Achievement and Critical Thinking}

The learning process which is based on critical thinking is needed, especially in getting the goals of learning (Amrullah et al., 2018). Students who have higher critical thinking criteria tend to have better academic performance, as well as those with average and lower critical thinking (Fong, Kim, Davis, Hoang, \& Kim, 2017). The ability to analyze and interpret is the part of the planning process while the ability to evaluate, inference, and to make deduction are the part of making a decision process (D'Alessio, Avolio, \& Charles, 2019). Critical thinking disposition is also able to increase the effectiveness of student learning in the classroom (Fung, 2017).

According to Pitt et al., (2015), critical thinking is useful for preparing everything needed by students in the learning process. Other research shows that there is a significant result between score, which is gotten from students with their academic performance (Pitt et al., 2015). Students' achievement and critical thinking are two psychological aspects which have been proven to get a lot of improvement when processed using online-based media (Esteves et al., 2018). The use of online-based media such as Kahoot allows students to prepare themselves as well as possible in the face of an exam that will be given (Licorish, Owen, \& Daniel, 2017). This continues to their ability to prepare themselves, put themselves in the right situation, choose the best choice according to what they understand and try themselves to be prepared and always active in dealing with various severe social and environmental stimuli (Plump \& LaRosa, 2017). 


\section{METHOD}

This preliminary study is conducted using experimental pretest-posttest one group only design (Stephens, Matzke, \& Hayes, 2018; Weger \& Wagemann, 2015). The aim of this method is to see the effect of using Kahoot as an evaluation method based digital which is hopeful to improve students' achievement and their critical thinking dispositions. Samples were chosen by using a purposive sampling method where a researcher can select the subjects based on the criteria which were decided before the time sampling (Azwar, 2007, 2016). Samples who are in listed as a student in research methodology and psychometric courses in February until June 2019 period. All subjects who were participating in the research got the informed consents as a form of their willingness to follow the research.

The experimental study was done for 4 weeks, where the first week, subjects will be getting the material according to the courses guideline. The second week, they are given a set of multiple questions with using a paper-based test examination. In the third week, they get knowledge about how to use Kahoot as an evaluation method in their learning process and in the last week, subjects were given the same and parallel a set of questions using Kahoot media. After that, they also are given an additional questionnaire that measures critical thinking disposition as a form of validated criteria of learning achievement. Further qualitative analysis was carried out to get students' personal understanding of whether Kahoot's use was able to improve critical thinking indicators experienced by students before and after learning using Kahoot.

This preliminary study uses two measurements which were made by the researcher that measure students' learning achievement and critical thinking disposition. The learning achievement measurement tool is made by the method of preparing a cognitive test according to the material to be tested (Ramdani, 2018). The results are two forms of a set of questions that measure the learning achievement, each of which consists of 20 multiple choice questions with 4 answer choices. While the second measuring instrument is a critical thinking disposition scale that is made by modifying the theory of critical thinking (Facione et al., 1995; Facione, 1990). Analysis of the data used in this preliminary study was a Spearman correlation for the relationship of two scores, while for the test using Kahoot using a different test paired sample test.

\section{RESULTS AND DISCUSSION}

The preliminary study was carried out by looking at the differences in the pretest and posttest scores in 60 psychology students involved during the experimental period. Subjects consisted of 14 men (23\%) and 46 women $(77 \%)$ who were divided into two classes proportionally. But before a different test, is carried out, all the scores will be tested for normality test.

Table 1. One-sample kolmogorov-smirnov test

\begin{tabular}{lll}
\hline Variable & Sig. & Test Distribution \\
\hline Pretest & .730 & Normal \\
Posttest & .659 & Normal \\
Total Score & .828 & Normal \\
Critical Thinking & .923 & Normal \\
\hline
\end{tabular}

Based on the results of the normality test in table 1 , all the scores tested were normally distributed because the significance values produced to meet the statistical normality standard ( $>.05)$ where if the significance value of the score was above .05 then the data were normally distributed. All the data are correlated to see the relationship with the data being tested (see table 2).

Table 2. Correlations

\begin{tabular}{lllll}
\hline Variable & Pretest & Posttest & Total Score & Critical Thinking \\
\hline Pretest & 1 & .138 & .063 & .153 \\
Posttest & .138 & 1 & -.052 & -.067 \\
Total Score & .063 & -.052 & 1 & .231 \\
Critical Thinking & .153 & -0.67 & .231 & 1 \\
\hline
\end{tabular}


The information in table 2 explains the very weak relationship between pretest and posttest score (.138) so that with this result, further analysis can be done to find out the difference in scores in the experimental group. Other data also explain the moderate correlation between student achievement scores and their critical thinking characters with a correlation coefficient of .231 (see table 2).

Table 3. Paired samples test

\begin{tabular}{llll}
\hline & T & df & Sig. \\
\hline Pretest - Posttest & -3.063 & 59 & .003 \\
\hline
\end{tabular}

The difference in pretest and posttest scores with paired sample test analysis produces a significance of .003 (see table 3 ). This shows that if the significance value is less than 0.05 , then the significant difference in the pretest and posttest scores is significant, which means that the form of treatment used is able to improve learning achievement.

The use of the Kahoot platform is one of the alternative media that can be done by teachers in utilizing technological progress in a positive direction. Learning activities that are made with interesting and not boring conditions will increase the motivation to instil students to take part in the activity (Licorish et al., 2017). Research conducted by Plump \& LaRosa (2017) shows that Kahoot's media contributes to improving student engagement and learning experience. In addition, this media is also able to make students more focused on facing all the forms of questions they receive (Plump \& LaRosa, 2017). Psychologically, the use of Kahoot is able to provide a pleasant feeling for students because of it occurs a biological process that is received by the body by listening and seeing the display presented in the media (Licorish et al., 2017). Specifically, several related studies also provide information about the benefits of using this media. Explaining Kahoot is very helpful for students in testing their abilities in memorizing terms in science (Pede, 2017).

Research on Kahoot's media is very much related to various psychological aspects that not only affect the prestige of student learning, these media are also very closely related to the dynamics of critical thinking possessed by someone (Fong et al., 2017). The use of media that involves kinetic responses and raises curiosity about the object to be learned is closely related to the critical thinking character possessed (Plump \& LaRosa, 2017). The more critical someone is about the things that will be learned, it will increase the effort involved to get the best results (Dehghani, Mirdoraghi, \& Pakmehr, 2011). The results showed that moderate correlations between critical thinking and the restoration of learning meant that there was a significant correlation between these two variables. Although not yet tested for the effect of Kahoot on increasing critical thinking of students in this study, but from the initial assumptions of the researcher and strengthened by the results of the related literature analysis it can be predicted that Kahoot might also have an impact on increasing students' critical thinking. The use of Kahoot's media, which is consistent and directed, equipped with adequate technological quality, is considered to determine the success of the learning process of students in the classroom.

Additional interviews were conducted to find out how students feel and experience when using Kahoot as an evaluation instrument for their learning. The results of the interview support previous research that using Kahoot allows students to be able to think critically about the situation they are facing in relation to the subject matter being tested. In addition to being able to increase their interest and seriousness in learning and working on problems. Kahoot also plays a role in providing a new and more pleasant atmosphere. Although the results of the correlation between Kahoot and critical thinking have not been explored further, this research proves that the use of fun and challenging media can increase students' seriousness in facing lessons.

\section{CONCLUSION}

The preliminary study shows the informative description about the importance of using Kahoot as an innovative, attractive, and an effective media platform in the learning process. Some things that must be considered in the future include the quality of the material that will be applied in Kahoot must be clearly and properly validated, the use of quality internet and Kahoot' supporting media must be adequate, and the experimental procedure mode must clearly measure various other related psychological attributes. Further studies will also look at the psychological factors that occur during the administration of the Kahoot instrument by using a deep qualitative approach. 


\section{ACKNOWLEDGEMENT}

This research is a longitudinal collaboration which is conducted by the Faculty of Psychology UIN Sunan Gunung Djati Bandung with the Center for Educational Assessment (PUSPENDIK), Agency of Research and Development, Ministry of Education and Culture of Indonesia.

\section{REFERENCES}

Amrullah, S., Tae, L. F., Ramdani, Z., Irawan, F. I., \& Prakoso, B. H. (2018). Studi sistematik aspek kreativitas dalam konteks pendidikan. Psympathic: Jurnal Ilmiah Psikologi, 5(2), 187-200. doi.org/10.15575/psy.v5i2.3533

An, D., \& Carr, M. (2017). Learning styles theory fails to explain learning and achievement: Recommendations for alternative approaches. Personality and Individual Differences, 116, 410-416. doi.org/10.1016/j.paid.2017.04.050

Azwar, S. (2007). Metode penelitian. Yogyakarta: Pustaka Pelajar.

Azwar, S. (2016). Konstruksi tes kemampuan kognitif (Edisi 1, C). Yogyakarta: Pustaka Belajar.

Boa, E. A., Wattanatorn, A., \& Tagong, K. (2018). The development and validation of the Blended Socratic Method of Teaching (BSMT): An instructional model to enhance the critical thinking skills of undergraduate business students. Kasetsart Journal of Social Sciences, 39(1), 81-89. doi.org/10.1016/j.kjss.2018.01.001

Boticki, I., Baksa, J., Seow, P., \& Looi, C. K. (2015). Usage of a mobile social learning platform with virtual badges in a primary school. Computers and Education, 86, 120-136. doi.org/10.1016/j.compedu.2015.02.015

D'Alessio, F. A., Avolio, B. E., \& Charles, V. (2019). Studying the impact of critical thinking on the academic performance of executive MBA students. Thinking Skills and Creativity, 31, 275-283. doi.org/10.1016/j.tsc.2019.02.002

Dehghani, M., Mirdoraghi, F., \& Pakmehr, H. (2011). The role of graduate students' achievement goals in their critical thinking disposition. Procedia - Social and Behavioral Sciences, 15, 2426-2430. doi.org/10.1016/j.sbspro.2011.04.121

Dellos, R. (2015). Kahoot! A digital game resource for learning. International Journal of Instructional Technology and Distance Learning, 12(4), 49-52. $\quad$ Retrieved http://citeseerx.ist.psu.edu/viewdoc/download?doi=10.1.1.694.5955\&rep=rep1\&type=pdf\#page=53

Dunn, T. J., \& Kennedy, M. (2019). Technology-enhanced learning in higher education; motivations, engagement and academic achievement. Computers and Education, 137, 104-113. doi.org/10.1016/j.compedu.2019.04.004

Esteves, M., Pereira, A., Veiga, N., \& Vasco, R. (2018). Teaching and learning in a digital world. Advances in Intelligent Systems and Computing, 715, 499-506. doi.org/10.1007/978-3-319-73210-7

Facione, N. C., Facione, P. A., Sanchez, G., \& Gainen, J. (1995). The disposition toward critical thinking. Journal of General Education, 44(1), 1-125. doi.org/10.2307/27797240

Facione, P. A. (1990). Critical thinking- A statement of expert consensus for purposes of educational assessment and instruction (The Delphi Report). California State University.

Fong, C. J., Kim, Y., Davis, C. W., Hoang, T., \& Kim, Y. W. (2017). A meta-analysis on critical thinking and community college student achievement. Thinking Skills and Creativity, 26, 71-83. doi.org/10.1016/j.tsc.2017.06.002

Fung, D. (2017). The pedagogical impacts on students' development of critical thinking dispositions: Experience from Hong Kong secondary schools. Thinking Skills and Creativity, 26(November 2016), 128-139. doi.org/10.1016/j.tsc.2017.10.005

Gómez-Peña, G., Sifuentes, R., \& Finch, M. (2015). Technology: Learning can be fun and games. Gifted Child Today, 60(1), 33-39. doi.org/10.1080/00043249.2001.10792048

Ismail, M. A.-A., \& Mohammad, J. A.-M. (2017). Kahoot: A promising tool for formative assessment in medical education. Education in Medicine Journal, 9(2), 19-26. doi.org/10.21315/eimj2017.9.2.2

Liao, C. W., Chen, C. H., \& Shih, S. J. (2019). The interactivity of video and collaboration for learning achievement, intrinsic motivation, cognitive load, and behaviour patterns in a digital game-based learning environment. Computers and Education, 133, 43-55. doi.org/10.1016/j.compedu.2019.01.013

Licorish, S. A., Owen, H., \& Daniel, B. K. (2017). "Go kahoot!" Enriching classroom engagement, motivation and learning experience with games. Proceedings of the 25th International Conference on Computers in Education. New Zealand: Asia-Pacific Society for Computers in Education, 755-764. Retrieved from https://www.researchgate.net/publication/322150947

Lin, D. T. A., Ganapathy, M., \& Kaur, M. (2018). Kahoot! It: Gamification in higher education. Pertanika Journal of Social Sciences and Humanities, 26(1), 565-582. 
Pede, J. (2017). The effects of the online game Kahoot on science vocabulary acquisition Part of the Science and Mathematics Education Commons, and the Special Education and Teaching Commons. Retrieved from http://rdw.rowan.edu/etdhttp://rdw.rowan.edu/etd/2405

Pitt, V., Powis, D., Levett-Jones, T., \& Hunter, S. (2015). The influence of critical thinking skills on performance and progression in a pre-registration nursing program. Nurse Education Today, 35(1), 125-131. doi.org/10.1016/j.nedt.2014.08.006

Plump, C. M., \& LaRosa, J. (2017). Using Kahoot! in the Classroom to Create Engagement and Active Learning: A Game-Based Technology Solution for eLearning Novices. Management Teaching Review, 2(2), 151-158. doi.org/10.1177/2379298116689783

Ramdani, Z. (2018). Construction of academic integrity scale. International Journal of Research Studies in Psychology, 7, 87-97. doi.org/10.5861/ijrsp.2018.3003

Ramdani, Z., Widyastuti, T., \& Ferdian, F. R. (2018). Penerapan analisis teori klasik, model rasch, dan computer based test moodle : Sebuah pilot studi. Indonesian Journal of Educational Assessment P-ISSN, 2(1), 21-30.

Sasson, I., Yehuda, I., \& Malkinson, N. (2018). Fostering the skills of critical thinking and question-posing in a project-based learning environment. Thinking Skills and Creativity, 29, 203-212. doi.org/10.1016/j.tsc.2018.08.001

Stephens, R. G., Matzke, D., \& Hayes, B. K. (2018). Disappearing dissociations in experimental psychology: Using state-trace analysis to test for multiple processes. Journal of Mathematical Psychology, (XXXX). doi.org/10.1016/j.jmp.2018.11.003

Weger, U., \& Wagemann, J. (2015). The challenges and opportunities of first-person inquiry in experimental psychology. New Ideas in Psychology, 36, 38-49. doi.org/10.1016/j.newideapsych.2014.09.001

West, D. M. (2013). Mobile learning: Transforming education, engaging student, and improving outcomes. Center for Technology Innovation at Brookings, (September).

Yapıcı, İ. Ü., \& Karakoyun, F. (2017). Gamification in biology teaching: A sample of Kahoot application. Turkish Online Journal of Qualitative Inquiry, 8(4), 396-414. doi.org/10.17569/tojqi.335956 